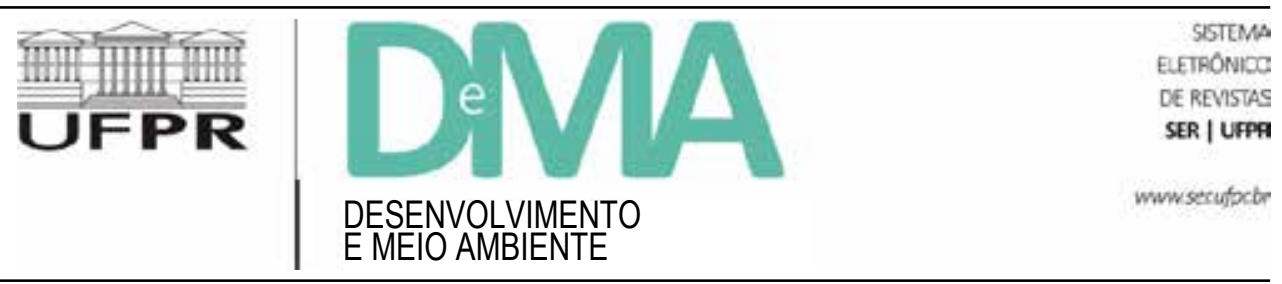

\title{
Geopoética do Semiárido brasileiro: a Estação Ecológica do Raso da Catarina em Arquitetura \& Canção
}

\section{Geopoethics of the Brazilian Semiarid: The "Raso da Catarina" Ecological Station in Architecture \& Song}

\author{
Francisco Fernando Livino de CARVALHO ${ }^{1,2^{*}}$, Luiza Corral Martins de Oliveira PONCIANO1 \\ ${ }^{1}$ Universidade Federal do Estado do Rio de Janeiro(UNIRIO), Rio de Janeiro, RJ, Brasil. \\ ${ }^{2}$ Instituto Chico Mendes de Conservação da Biodiversidade(ICMBio), Brasília, DF, Brasil. \\ *E-mail de contato: francisco.livino@icmbio.gov.br
}

Artigo recebido em 22 de abril de 2020, versão final aceita em 4 de setembro de 2020, publicado em 18 de dezembro de 2020.

RESUMO: A Geopoética oferece uma abordagem de construção do conhecimento que é ao mesmo tempo científica, filosófica e poética, sendo um campo pertinente para alicerçar novos produtos interpretativos para as unidades de conservação (UC) federais. O estudo preliminar para uma base de apoio à pesquisa na Estação Ecológica do Raso da Catarina (região de Paulo Afonso-BA) ilustra uma postura projetual que se contrapõe à corriqueira tendência arquitetônica de implantação de edificações, que buscam se configurar como uma "marca" na paisagem. Ao contrário, agindo geopoeticamente, desejamos que a edificação venha a se materializar como uma "eclosão" das forças expressivas da Natureza daquele lugar, da paisagem que a receberá, concebendo uma edificação o mais possível integrada ao local. Tal eclosão Geopoética vai além e entrelaça a Arquitetura com poemas e canções, por serem linguagens que se complementam e se retroalimentam na tradução das paisagens do semiárido brasileiro, com o intuito de promover um encantamento social pelas nossas áreas protegidas. Fazer da Arte uma ferramenta de gestão ambiental e estruturar a promoção do encantamento como uma política pública são os caminhos sugeridos aqui para se reconciliar a sociedade contemporânea com os ambientes naturais.

Palavras-chave: geopoética; interpretação ambiental; arquitetura; unidades de conservação.

ABSTRACT: Geopoetics offers a scientific, philosophical and poetic unified approach to knowledge construction, being a pertinent field to support new interpretative products for federal protected areas (UC) in Brazil. The preliminary study for a research base in the "Raso da Catarina" Ecological Station (Paulo Afonso - BA region) illustrates 
a design stance that opposes the current architectural trend that leads to the implantation of buildings which seeks to configure themselves as a "brand" in the landscape. On the contrary, acting geopoetically, we want to materialize the building as an "outbreak" of the expressive forces of Nature in that place, the landscape that will receive it, conceiving a building integrated with the place as much as possible . Such a Geopoetics outbreak goes beyond and interweaves Architecture with poems and songs, as languages that complement and nurture themselves as translations of the Brazilian semiarid landscapes, with the aim of promoting a social enchantment for our protected areas. Making Art an environmental management tool and structuring the promotion of enchantment as a public policy are ways suggested here to reconcile contemporary society with the natural environments.

Keywords: geopoetics; environmental interpretation; architecture; protected areas.

\section{Introdução: interpretando a paisagem}

A prática da visitação em unidades de conservação (UC) carrega a responsabilidade e o potencial de ser um dos caminhos onde encontramos estímulos, (re)conhecimentos e afetos pela Natureza, contribuindo para uma necessária e urgente reconciliação entre a sociedade contemporânea e o nosso berço natural (Cabrita, 2017). Muitas vezes, entretanto, pode ser essencial provocar o visitante para que ele se aprofunde nessa imersão, por meio de atividades de sensibilização que visam (re)criar as memórias e conexões afetivas entre o ser humano e a Natureza selvagem (Hanai \& Netto, 2006). Para tal, faz-se importante investir no desenvolvimento de formas de interlocução múltiplas e complementares, incluindo estímulos sensoriais diversos (ICMBio, 2018).

A interpretação dos atributos e fenômenos da Natureza é atividade humana desde tempos imemoriais. Ela nasce da necessidade de expressão e da sociabilidade do homem, sua capacidade atávica de traduzir e transmitir conhecimentos e sensações (ICMBio, 2018). A Interpretação Ambiental, por sua vez, é uma prática gerencial que se propõe a provocar e sensibilizar o visitante em relação aos atributos naturais protegidos pelas unidades de conservação (ou outras áreas especialmente protegidas), se valendo de variadas linguagens para comunicar os encantos da Natureza e a importância de sua conservação. "É uma arte que combina muitas artes" (Tilden, 1977): painéis e banners interpretativos, documentários audiovisuais, trilhas guiadas, performances, dioramas, dentre outros produtos que buscam aproximar o público visitante das UC às mensagens da Natureza.

A Arte aplicada como uma ferramenta de gestão é o que propomos neste artigo, propiciando a formação de uma postura crítica, pautada na Geopoética, frente à crise socioambiental do nosso tempo (Leme \& Neves, 2007). Em um contexto global no qual a qualidade de vida é muito vinculada com a capacidade de consumo e a sociedade confunde o "bem viver" com um "viver para ter", tem-se as justificativas para a assimetria entre as dinâmicas social e ecológica que caracterizam a contemporaneidade (Sampaio, 2018).

Se no tocante aos recursos naturais vivenciamos uma realidade de sobre-exploração e esgotamento, no campo das artes e da cultura vive-se hoje 
uma crise estética e subjetiva decorrente de uma massificação cultural globalizada, que molda as preferências populares por meio de fórmulas padronizadas, repetitivas e alheias às referências culturais das comunidades. Arte e cultura são transformadas em objetos de consumo como outros quaisquer, e seu público "consumidor" se torna alienado ao bem cultural e à própria vida (Oliveira, 2018).

Em vista desse cenário, acreditamos na fertilidade do solo brasileiro (representado por suas paisagens, ecossistemas e espécies) para rebrotar uma semente de sustentabilidade, pautada em profundas raízes culturais, capazes de sustentar copas abertas ao mundo.

Desse modo, entrelaçamos Arquitetura, poemas e canções que se complementam e se reforçam no discurso de louvação à paisagem (no caso a caatinga) e na mensagem da conservação e da valorização de nosso patrimônio natural e cultural.

As canções, associadas (ou não) a outras formas de mídia, tais como audiovisuais ou performances, tanto podem se conjugar com as edificações (como, por exemplo, sendo atrações em exposições interpretativas de centros de visitantes), como podem mirar um público urbano, inicialmente distante das UC, pelas inúmeras plataformas de divulgação atualmente disponíveis. O objetivo é oferecer lentes sensitivas aos visitantes e levar as paisagens protegidas para muito além de seus perímetros legais, por meio das "asas" que a música oferece em seus variados meios de veiculação, indo além dos ecoturistas.

O conceito de Paisagem entrelaça o tangível e o intangível, no sentido de se encontrar a "alma do lugar" (Mendonça \& Neiman, 2000; Kozel, 2012). Mais que um espaço físico em si, o conceito de Paisagem retrata a forma de se perceber aquele espaço. Amadurecendo o conceito, Kozel (2012) descreve a paisagem como "o resultado da contemplação, primeiramente no sentido ótico e em seguida espiritual da Natureza, correlacionando os diversos objetos e a imaginação subjetiva dos mesmos". Ou seja, muito além dos elementos visíveis e concretos, se entrelaçam o empírico, a criatividade e a sensibilidade, que, por sua vez, estarão sempre relacionados aos aspectos culturais de um espaço-povo-tempo. Embora a autora nos descreva a "contemplação no sentido ótico", a percepção da paisagem vai além e toca os demais sentidos, o que nos leva ao conceito de paisagem sonora, explorado por Kozel (2012) sob a tríade "olhar, sentir e ouvir" a Natureza. Nesse entrelaçamento entre as linguagens plásticas e sonoras, focamos aqui na materialização de uma síntese da paisagem pela Arquitetura e canções.

Assim, as linguagens (geo)poéticas se materializam visando alcançar subjetividades e provocar intersubjetividades construtoras de uma postura social em relação ao ambiente (Andrade \& Sorrentino, 2013), pautadas pelo respeito e pelo encantamento. É fundamentalmente no que se acredita e se aposta: um novo olhar, capaz de promover outras práticas sociais, um novo sentir que influenciará outro pensar e agir.

O foco na Estação Ecológica do Raso da Catarina, UC federal localizada na região de Paulo Afonso, na caatinga baiana, se apresenta como uma proposta piloto, capaz de ilustrar uma postura projetual e compositiva que se aplica e pode ser adaptada para qualquer outro bioma brasileiro. Buscando uma uniformidade conceitual e metodológica baseada na Arquitetura e nas Artes, o intuito é refletir a diversidade biológica, geológica e cultural do país numa heterogeneidade de expressões unificada 
pelo espelhamento da paisagem local nos projetos realizados. Embora aplicada aqui em uma categoria de UC que não permite a visitação com fins recreativos, a metodologia proposta a seguir pode ser replicada para as demais categorias, em especial os parques nacionais, cujos objetivos principais incluem a recreação, com o claro propósito de aproximar sociedade e conservação ambiental.

\section{Uma abordagem geopoética}

A Geopoética, que abrange as diversas formas de relação dos seres humanos com o planeta Terra, seguindo a linha mais abrangente proposta por Kenneth White em 1979 (Ponciano, 2018), responde pelo amálgama de uma abordagem ao mesmo tempo científica, filosófica e poética, que alicerça expressões técnico-artísticas (arquitetura, poesia, imagens, canções...) cuja fonte dos seus elementos de linguagem é a própria paisagem natural protegida, à qual devem servir. Ponciano (2018), ao relacionar o fazer poético com a investigação científica, afirma que a pesquisa acadêmica possibilita a "criação e a partilha de performances vivas, viscerais e profundas", decorrentes da intimidade que a investigação oferece ao criador que se aprofunda no conhecimento relacionado ao tema de sua criação.

Cada vez mais, a noção de fruição e relação existencial com o espaço vem ganhando valor (Crapez, 2017), sendo necessário promover uma ressignificação das experiências, oferecendo vivências nos ambientes naturais e trabalhando a oferta de linguagens inteligíveis (Tuan, 2013a) a um público crescentemente citadino. Portanto, é responsabilidade do planejamento ecoturístico propor estratégias que façam com que a visita a uma área natural vá além de um mero "consumo" da paisagem (Mendonça \& Neiman, 2000), ou, como afirma Tuan (2012), uma "coleção" de carimbos de parques nacionais no passaporte. Este costume, muito comum nos EUA, pode ser encontrado aqui no Brasil, por exemplo, no programa de Passaporte de Trilhas do Estado de São Paulo, da Fundação Florestal. Os resultados que aqui se apresentam são, portanto, propostas para estimular e aperfeiçoar a interlocução do visitante urbano com as paisagens naturais, ofertando novas traduções e sínteses dessas paisagens, em variadas linguagens (Hanai $\&$ Netto, 2006).

A Geopoética oferece um terreno de encontros e estímulos recíprocos entre Turismo, Ciências Ambientais, Arquitetura, Geociências, Artes, Biologia, Física, Química e outras disciplinas diversas, desde o momento em que se trabalhe com estas sem se prender a seus espaços isolados, abrindo-se a encontros inusitados, em uma transdisciplinaridade amplificada (Ponciano, 2018).

Esta procura reflete as preocupações de White (2014), quando o autor destaca que "se o 'meio ambiente' [...] não é preservado e mantido em toda sua complexidade, a existência, em breve, não terá mais base, a cultura não terá mais fundamento, e as práticas particulares, mais nenhum sentido".

Diversos autores visitam a fonte talhada inicialmente por Kenneth White para ampliar este conceito e saciar a sede de suas jornadas, como Kozel (2012), quando nos é sugerida a tríade entre olhar, sentir e ouvir como proposta para apreender a Geopoética. Já Crapez (2015) afirma que "a Geopoética, mais que uma poética nascida das relações entre Arte e meio ambiente, é uma poética que emerge dessa consciência aguçada da consubstancialidade do ser humano com seu meio". 
Esta relação entre tangível e intangível é algo que requer necessariamente a transdisciplinaridade à qual se refere Ponciano (2018), justamente por não ser possível abarcá-la plenamente pela Ciência tradicional e a sua especialização. A reflexão, nesses casos, nasce exatamente "entre a terra dos pensamentos e sentimentos" (Guimarães, 2002). Esta autora demonstra as diferentes formas pelas quais a geografia humanista estuda a paisagem, "segundo nossas experiências e percepções", ultrapassando os limites específicos da Ciência e legitimando as Artes plásticas e literárias como expressões dessa percepção e, portanto, dessa construção de conhecimento.

Conceitos que inspiram o fazer aqui relatado, tais como a transdisciplinaridade, a geografia humanista e a Geopoética, embora relativamente recentes, já eram realizados pelos grandes naturalistas do século XVIII, quando retratavam e descreviam o sentimento de encantamento diante da grandeza da Natureza: "mais do que um objeto da Ciência, uma verdadeira obra de Arte" (Roncaglio, 2009).

Apostamos, portanto, numa pluralidade de linguagens complementares capazes de estimular sentidos e ideias variadas no praticante do Ecoturismo (e também no ecoturista virtual), sugerindo a adoção de uma política pública de encantamento pela Natureza, que encontrará seus porta-vozes nos profissionais da Interpretação Ambiental, sejam eles biólogos, geógrafos, arquitetos, educadores ou oriundos de qualquer outra formação acadêmica ou técnica, estimulando uma reconciliação entre a sociedade contemporânea e o nosso berço natural, palco dos dramas encenados no planeta.

\section{As trilhas percorridas (metodologia)}

Para traduzir o semiárido brasileiro numa abordagem geopoética, de modo a construir as linguagens que serão expostas no presente artigo, diversas trilhas metodológicas foram percorridas. Os caminhos que veremos a seguir, embora relatem especificamente os que foram trilhados para a concepção dos produtos que compõem este artigo, se prestam à materialização de uma metodologia que pretende orientar a elaboração de produtos interpretativos (inclusive a Arquitetura), independentemente do bioma ou categoria de manejo das UC analisadas.

\subsection{Levantamento bibliográfico e documental}

Constituindo as lentes de análise para as questões investigadas, foram realizadas pesquisas nos campos da Geopoética, Geografia, Ecologia, Arquitetura, Interpretação Ambiental e Ecoturismo, dentre outros, além de documentos oficiais produzidos pelos órgãos gestores das UC enfocadas, tais como: planos de manejo, mapas, relatórios e gráficos. Sempre que possível, destacamos a importância da inclusão de dados não publicados (cadernetas de campo, fotografias, filmes, ilustrações, mapas, perfis estratigráficos, etc.), e das coleções de museus, universidades e outros institutos de pesquisa que contenham exemplares biológicos, geológicos e culturais coletados no local, considerando a possibilidade de alguns destes não serem mais encontrados in situ (no seu lugar de origem). 


\subsection{Visitas de campo}

As percepções das particularidades que compõem a essência paisagística da Estação Ecológica (ESEC) do Raso da Catarina (BA), a "alma do lugar" (Mendonça \& Neiman, 2000; Kozel, 2012), foram colhidas em uma visita de campo realizada no ano de 2007. Nessa ocasião se fez diversos registros fotográficos e ainda mais registros imateriais, colhidos na retina e no espírito. A UC foi percorrida tanto por meio terrestre, em veículos motorizados e trilhas a pé, quanto por helicóptero, de onde se pôde perceber, por sobrevoo, toda a magnitude da biodiversidade e geodiversidade da região. Consideramos que os trabalhos de campo são essenciais para uma "incorporação" da paisagem de cada local, mas a forma, a duração e o foco nos elementos locais podem variar de acordo com a formação acadêmica e vivências anteriores de quem estiver realizando a pesquisa. Sugerimos que a visita de campo contemple a maior diversidade possível de elementos biológicos, geológicos e culturais, além dos diferentes períodos do dia e se possível as variações pelas estações do ano.

\subsection{Absorção artística}

A leitura de autores como Euclides da Cunha (Cunha, 2016) e Rachel de Queiroz (Queiroz, 2006); a audição atenta e devota da obra do cancioneiro de Elomar Figueira (Mello, 1973; 1981), bem como outros artistas oriundos da caatinga, como Xangai (1997), Mestre Ambrósio (1998; 2001) e Cordel do Fogo Encantado (2002); filmes como Árido Movie (Ferreira, 2005), Central do Brasil (Salles, 1998), A Noite do Espantalho (Ricardo, 1974) e O dragão da maldade, contra o santo guerreiro (Rocha, 1969); os cordelistas e gravadores do sertão; o mestre xilogravurista Gilvan Samico (Samico, 1998) como referência especial; poetas sertanejos, tais como Jessier Quirino (Quirino, 1998 2005), Amazan (Amazan, 1994) e Chico Pedrosa (Pedrosa, 2001) foram fundamentais para absorver o espírito cultural do sertão nordestino a fim de apreender as cores e os traços a serem aplicados nas obras resultantes (a poesia escrita e a construída). Tais obras de arte foram absorvidas de forma empírica ao longo da vida dos autores, um pensar-sentindo, conforme exposto em um seminário de cultura luso-brasileira, na Faculdade de Letras da Universidade Federal Fluminense, nos anos 1990. Todas essas referências (e tantas outras) foram absorvidas com o tempo, sendo revisitadas sob uma ótica acadêmica ao longo da pesquisa para a concepção deste trabalho. Assim, indicamos que, de acordo com as peculiaridades do local, essa fase da pesquisa inclui, tanto quanto possível, referências nas várias Artes, aproveitando correlações prévias com o bioma enfocado por meio das memórias afetivas que brotam no corpo, integrando a "entidade artista" ao "ser" pesquisador acadêmico.

\subsection{Composições geopoéticas}

As composições textuais e musicais buscam empatia com o público por meio da mensagem e da forma, sendo tão importante o "que" se diz quanto o "como" se diz. As rimas e a poética se oferecem sedutoras, ampliando a atratividade da mensagem conservacionista, enquanto as características típicas dos ambientes protegidos (suas espécies, geologia, culturas e paisagens) compõem a narrativa das 
canções. Estas se estruturam sob tessituras musicais afins aos territórios, por meio de melodias, harmonias e ritmos que, apesar de coerentes com as suas paisagens sonoras (Torres \& Kozel, 2012) originárias, acabam por se configurar numa linguagem abstrata de leitura universal. Como exemplo, pode-se citar a estrutura métrica do martelo agalopado, estilo de poema utilizado por cordelistas e cantadores nordestinos, que serve de condutor para o poema musicado "Festa fresca, chuva boa", que retrata a caatinga, como referência e reverência ao Raso da Catarina. Lembramos aqui que essas composições podem ser realizadas por meio de parcerias com músicos, poetas, projetos de extensão de universidades e várias outras possibilidades, no intuito de conceber tais produtos.

\subsection{Concepção geopoética de Arquitetura}

Tal projeto se configurou como uma mescla de laboratório e campo, em que se buscou correlacionar as referências paisagísticas (colhidas na unidade de conservação, na literatura, em fotografias, iconografia, músicas, etc.) com a linguagem arquitetônica resultante, materializada pelas técnicas construtivas escolhidas, privilegiando as técnicas consagradas como bioconstrução. Novamente esta fase também pode ser efetivada por meio da formação de uma equipe transdisciplinar, na qual cada pessoa contribui com as suas experiências e aprende novos talentos ao longo do processo.

$\mathrm{O}$ que queremos destacar nessa metodologia é a postura geral no ato de conceber produtos in- terpretativos para as áreas protegidas se valendo da Geopoética. Uma postura referenciada nas práticas dos antigos pintores chineses, que, em vez de irem para o campo com suas tintas e cavaletes, preferiam flanar livremente um longo tempo pelas paisagens para depois exprimi-las, filtradas por suas emoções (Tuan, 2012). Os resultados que ilustram o presente trabalho são fruto de quase duas décadas de vivências nas UC brasileiras, tanto em atividade profissional quanto em atividades de lazer, ocasiões nas quais as duas formas de estar acontecem de maneira indissolúvel: mesmo durante o lazer não é possível conseguir se desvencilhar do olhar crítico de gestor e pesquisador, assim como o analista em exercício profissional não consegue abstrair seu sentir passional de amante da Natureza. Desse modo, as "almas" dos lugares vividos se mesclaram e são, hoje, parte integrante do espírito "geopoeta" dos autores, que se traduzem em cada uma das obras apresentadas.

Cabe, por fim, esclarecer que as duas últimas etapas descritas (3.4 e 3.5) se referem aos produtos específicos que compõem este artigo, no caso aos poemas e canções e à Arquitetura. $\mathrm{O}$ desafio de produzir produtos interpretativos, entretanto, poderá requerer linguagens diferentes destas, já que são inúmeras as suas formas de expressão. As três primeiras etapas descritas nesta metodologia são necessárias e devem ser adotadas independentemente do tipo de produto que nos seja requerido. Linguagens outras, que não poemas, Arquitetura e canções, poderão requerer a adoção de outras etapas específicas, que poderão ser adicionadas conforme o caso. 


\section{Os destinos alcançados: mirantes do semiárido (produtos interpretativos)}

\subsection{Geopoética do semiárido brasileiro em canções}

Não nos situamos mais no psiquismo, nem na sentimentalidade, mas na instrumentalidade e na investigação. O poeta não "se exprime" mais, ele é o estrategista de um tema, o protagonista de uma poética (White, 1999).

Como afirma White (1999) na citação que ilustra a epígrafe acima, a nossa poética se vale da investigação para promover o tema da conservação ambiental. Assim sendo, o poema bate asas, sem, no entanto, perder de vista o chão que lhe serve de suporte.
Em vista desta relação - poética versus lastro instrumental investigativo -, destrincharemos a seguir de maneira pormenorizada os motes e os resultados das canções que utilizamos para exaltar a Geopoética das áreas protegidas brasileiras, enfocando, para este artigo, suas referências e suas reverências ao semiárido brasileiro.

A primeira canção, intitulada "Cadê!?", é um misto de ode e grito de alerta. Não retrata especificamente um bioma ou uma unidade de conservação em particular, mas perpassa diversas reservas e paisagens brasileiras.

Como referência musical da composição tem-se a última faixa do álbum Fantasia leiga para um rio seco (Mello, 1981), que ocupa todo o seu "lado B”. Só a ilustração do encarte (Figura 1) já é uma obra de enorme expressividade Geopoética, pelos traços do artista Juraci Dórea! Intitulada "Amarra-

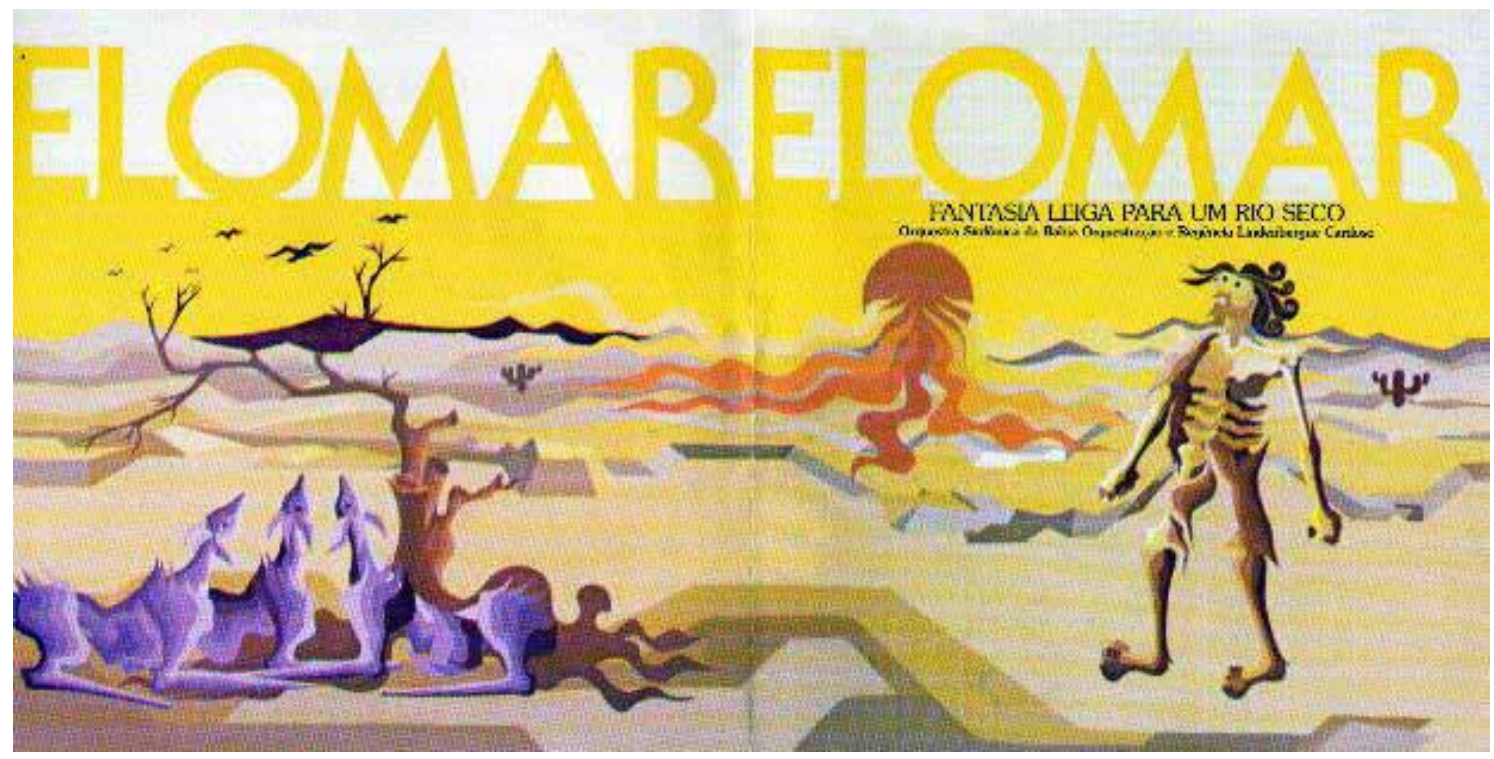

FIGURA 1 - Encarte do álbum Fantasia Leiga para um Rio Seco. FONTE: Fotografia do primeiro autor. 
ção", a letra compõe-se apenas dos seguintes versos: "Cadê os pé dos imbuzêro/ qui florava todo ano/ nas baxada e nas vereda mana mia/ cadê os pé d'imbu meu mano/ adeus pé dos imbuzêro". Sob a aura de um envoltório orquestral diversificado, os versos se repetem em variadas entonações sentimentais. Ao longo de seus mais de vinte minutos, alerta para uma destruição ambiental que desde os tempos do Brasil colônia vem agravando as condições climáticas do semiárido nordestino (Cunha, 2016). Foi com essa obra ecoando no subconsciente que surgiram os versos musicados de "Cadê!?"1.

Apresentamos a seguir as inspirações e correlações realizadas em cada trecho da música.

"Cadê!? No fim da tarde voam/ na beira da lagoa/ as nuvens de irerê/ cadê!?"

No início da década de 1980, a região oceânica de Niterói-RJ era ainda uma área relativamente remota, com características suburbanas, bem diferentes da efervescência expansionista que atingiu a região nas três últimas décadas. Naquela época, as lagoas presentes na região ainda abrigavam grandes populações de aves silvestres, o que se fazia perceber, por exemplo, pelas constantes vocalizações de bandos de marrecos irerê (Dendrocygna viduata) que, à noite, cruzavam os céus da região. Em determinada ocasião pôde-se registrar a chegada de incontáveis bandos dessas aves que praticamente nublaram os céus enquanto chegavam para pernoitar na Lagoa de Piratininga. O impacto sensível deste episódio reverbera até os dias de hoje e fortalece o encantamento pela vida selvagem, vindo a florescer, várias décadas mais tarde, nos versos iniciais da canção que apresentamos, materializando um forte desejo (que guia todo o presente trabalho) de propagar tal encanto, de expandir subjetividade visando provocar "intersubjetividade" (Andrade \& Sorrentino, 2013).

"Cadê!? Nos céus de brigadeiro/ as formações em "vê"/ dos bandos de colhereiros/ asas rosas em buquê/ cadê!?"

A ornitologia se vale de fotografias, gravações de cantos, coletas de espécimes, dentre outras técnicas de registros que descrevem e comunicam os hábitos e particularidades das espécies. Não se pode, certamente, caracterizar o verso acima como um registro científico, entretanto, a frase descreve e "registra" uma pequena "migração" em que cerca de dez ou quinze indivíduos de colhereiros (Platalea ajaja) atravessavam a enseada de Itacoatiara, $\mathrm{Ni}$ terói, colorindo um céu particularmente azul com suas plumagens reprodutivas de um rosa intenso. Tal comportamento, típico de outras espécies de aves, quando em voos coletivos, parece não ser comum em colhereiros (Figura 2), não tendo sido encontrados registros de tal comportamento na literatura especializada. A canção, portanto, poderia bem representar um inédito registro geopoético para a espécie.

"Cadê!? As matas de restinga/ praia, Piratininga o voo sangue do tiê/ cadê!?/ Não mais se vê.../"

O tiê-sangue (Ramphocelus bresilius), espécie endêmica da Mata Atlântica do litoral leste brasileiro (Castiglioni, 1998), era comum na região oceânica de Niterói, emprestando sua beleza

1 https://www.facebook.com/1578225595597895/videos/676984366367459

Desenvolv. Meio Ambiente, v. 55, Edição especial - Sociedade e ambiente no Semiárido: controvérsias e abordagens, p. 721-741, dez. 2020. 


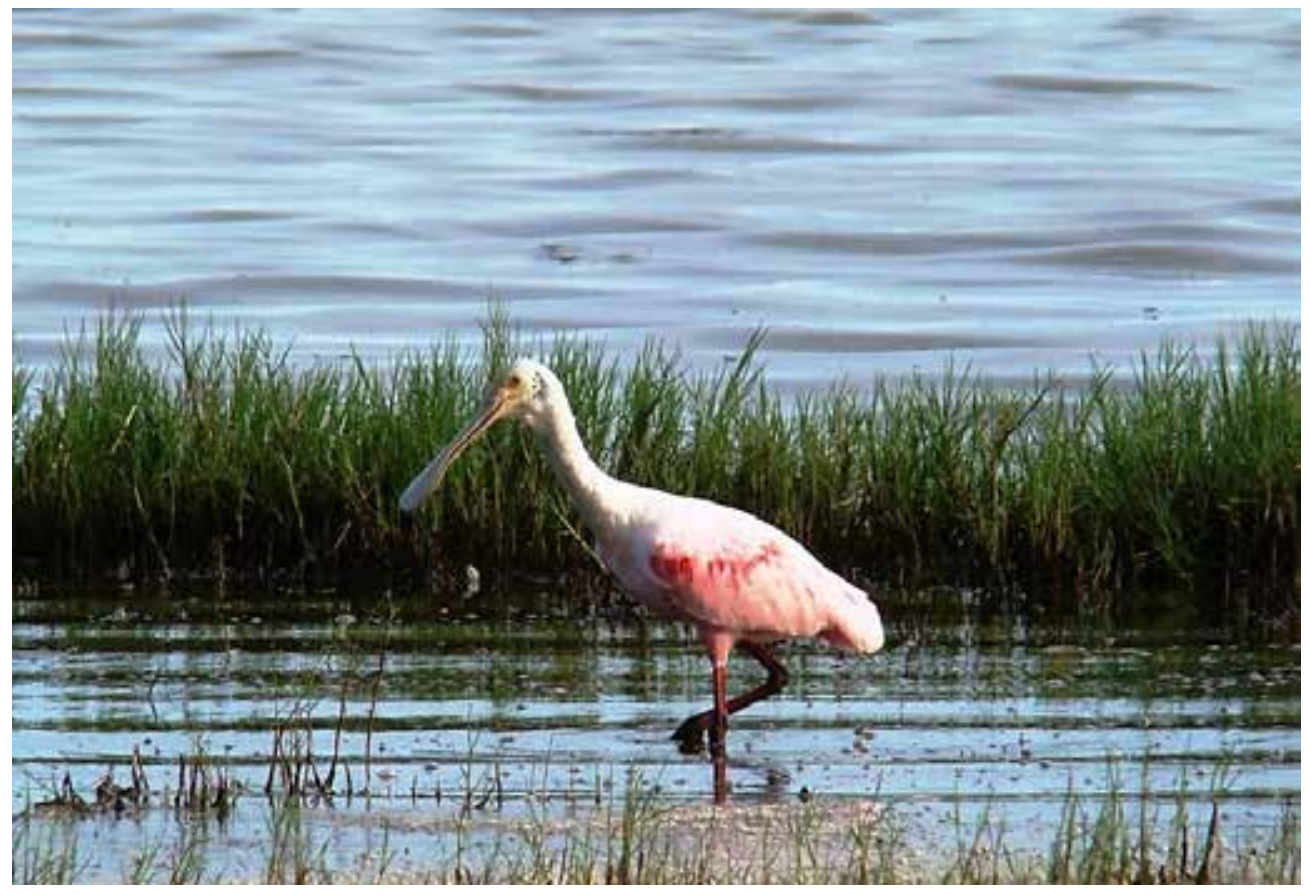

FIGURA 2 - Colhereiro na Lagoa de Piratininga.

FONTE: Fotografia do primeiro autor.

inconfundível às paisagens do município. Hoje praticamente desapareceu, junto com as restingas, que deram espaço à expansão urbana. ${ }^{2}$

"Hoje o que voa é a esperança/ daquilo que ainda trago de criança/ aos filhos poder dar como herança/ e a vida que resiste ser capaz de proteger:"

O desafio que se impõe ao serviço público, particularmente em uma agenda de notória fragilidade ante a arena política do país (Frey, 2000), é criar condições para superar limitações estruturais que criam um abismo entre a missão imposta e as condições disponíveis para enfrentá-la.
Propor inovações, tais como a utilização da música e da poesia como proposta de engajamento social, faz parte das estratégias de superação de tão vastos obstáculos.

"As matas da Bocaina/ banhados do Taim/ cerrados pantaneiros/variedades de sauim/ o rio Juruena/ águas do Japurá/ as aves de Noronha/ muriqui, tamanduá.../ Serra da Capivara/ Serra das Confusões/ Raso da Catarina/ variedades de sertões/ veredas e chapadas/Veadeiros, Diamantina/ a água cristalina que não cessa de verter/"

\footnotetext{
${ }^{2}$ Recentemente, durante a produção desse artigo, tive o júbilo de rever a espécie no Parque Natural Municipal da Ilha do Pontal, no limite norte da Lagoa de Piratininga, em Niterói-RJ.
} 
UC dos variados biomas nacionais são citadas num misto de adoração e convite, alertando para a responsabilidade em protegê-las. A Mata Atlântica, personificada pelo grandioso Parque Nacional da Serra da Bocaina (Rio de Janeiro e São Paulo); os imensos rios Juruena e Japurá, representando o bioma amazônico, que têm trechos de seus cursos protegidos respectivamente pelo Parque Nacional do Juruena-AM/MT e pela Estação Ecológica Juami-Japurá-AM (Figura 3); a Caatinga, ilustrada pelos Parques Nacionais da Serra da Capivara, da Serra das Confusões, ambos no Piauí, além do Parque Nacional da Chapada Diamantina e da Estação Ecológica do Raso da Catarina-BA, foco do presente trabalho, ambos em território baiano; enfim, a canção viaja pelo Brasil para ilustrar a megadiversidade do nosso cenário. As aves do Parque Nacional Marinho de Fernando de Noronha trazem o nosso bioma marinho-costeiro. Da região sul, nos Pampas gaúchos, citamos a Estação
Ecológica do Taim, impressionante berço de vida que rivaliza em abundância com o Pantanal. Este último, por fim, se junta ao Cerrado, bioma que o abraça, ilustrado pelo consagrado destino turístico protegido pelo Parque Nacional da Chapada dos Veadeiros. Ponteados com espécies da fauna silvestre, os versos destacam os serviços ambientais, numa alusão mais pragmática da importância desses territórios para a vida humana, além de seu valor imanente, nem sempre percebido. Talvez o mais cristalino dentre os serviços ambientais - explorando o duplo sentido da palavra - seja a proteção dos mananciais de água limpa que abastecem as populações Brasil afora. Vida que promove a vida e que se faz necessário proteger:

"a vida nos ensina/ é tempo de aprender/ que a vida que resiste/ é necessário proteger/ pra os filhos de outros filhos/ termos como responder:/ Cadê!?"

A canção se conclui com uma entonação tônica sobre a pergunta título: "Cadê!?”. Do mesmo modo

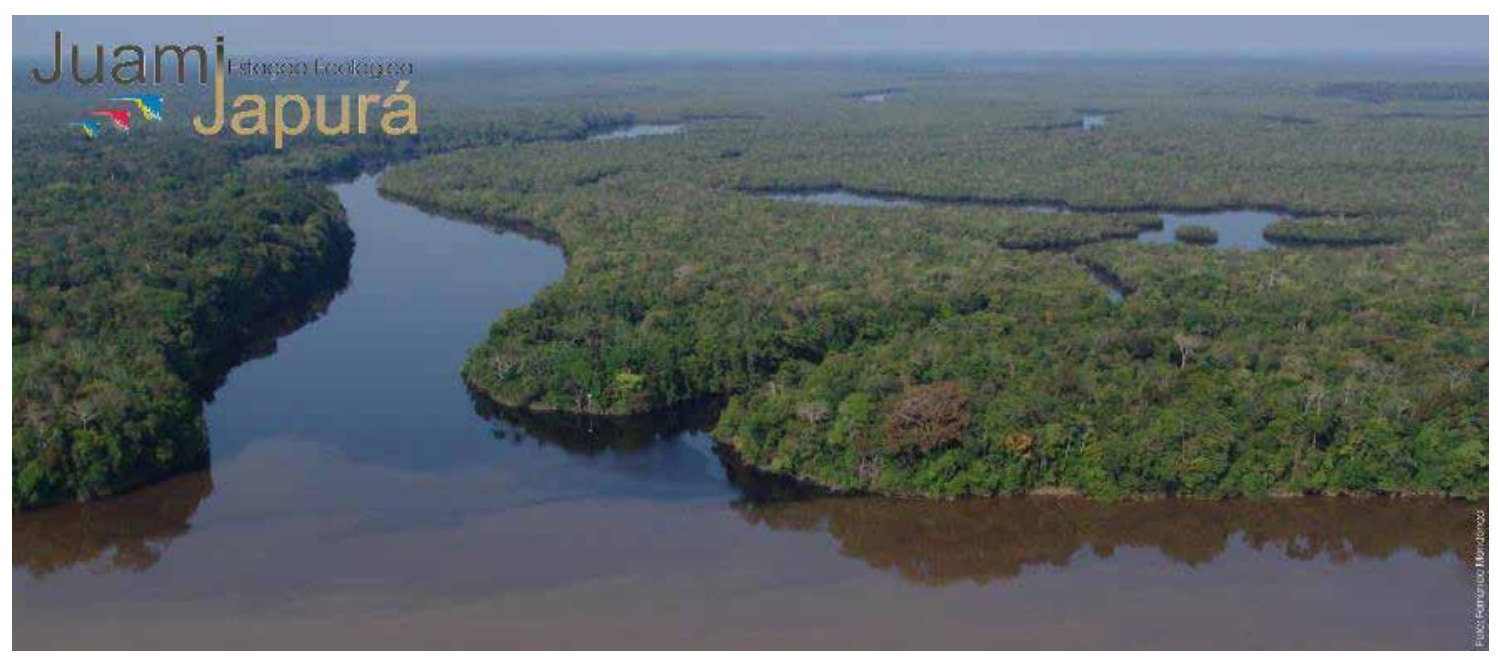

FIGURA 3 - Estação Ecológica Juami-Japurá. FOTO: Fernando Mendonça-INPA. 
que se quer promover o encantamento, se alerta para o rápido desaparecimento de paisagens e espécies promovido pelo nosso modelo de desenvolvimento e urbanização. Exclama-se a importância e a urgência de uma mudança de atitude de nossa sociedade contemporânea em relação às áreas naturais remanescentes, protegidas ou não.

A canção "Festa da Vida" é inspirada pela grandiosidade do Parque Nacional da Serra da Capivara, no município de São Raimundo Nonato, Piauí. Foi nessa ocasião, em meio ao coração seco do país, que se deu início a uma fértil nascente de canções, dentre as quais algumas são expostas neste artigo.

"É a festa da vida/ É a vida com pressa/ Que bebe a chuva bem-vinda/ Anseia a chuva que resta/ E enquanto Deus quer e São Pedro instrumenta a orquestra/ A Caatinga se enfeita e se faz de rica floresta/ O Sertanejo se ameiga/ Em um sorriso crescente/ Minha cabocla morena/ Me adocica a aguardente/ E enquanto Deus quer e São Pedro rega a semente/ Tem fartura na feira, tem festa, cordel e repente/ "A vida aqui só é ruim, quando não chove no chão"/ É o chão do vaqueiro eô.../ É cancão no facheiro/ Nuvens de passaredo/ Tem ninho no juazeiro/ É o cavalo e o gibão eô, eô.../ É o luar do sertão/ É a festa da vida/ No coração brasileiro!"

Único bioma exclusivamente brasileiro, a Caatinga costuma habitar a intersubjetividade do país sendo exclusivamente relacionada à seca e à miséria, fruto da nossa perniciosa lógica telejornalística de priorizar os fatos negativos.
Não à toa, a canção da banda pop mineira Skank quer inventar o "Antitelejornal" para "mostrar só o que é belo, para mostrar o essencial". Pois bem, o que a canção retrata é justamente a festa da vida na qual se transmuta a Caatinga, durante o período das chuvas. Durante o "inverno" e pelo período subsequente de sua influência, a região do semiárido é extremamente abundante em vida, refletindo uma riqueza fisiológica comovente que não encontra paralelo nas áreas de florestas mais úmidas do país (Cruz, 2018). Face à sazonalidade que, fatalmente, trará novo período de escassez, fauna e flora assumem um ritmo frenético de reprodução e fartura, enquanto as águas assim permitem ("enquanto São Pedro rega a semente"). Imediatamente após as primeiras chuvas, o ocre pardacento da paisagem se transmuta como mágica num verde intenso que esconde o tom do solo exposto e das rochas. As mais variadas espécies da fauna aparecem "não se sabe" de onde, sob a regência dos grandes bandos de pombas asa-branca (Patagioneas picazuro) e avoantes (Zenaida auriculata). "E não é à toa que as Djaniras no campo em flor são filhas do menor chuvisco" (França, 1979) ${ }^{6}$, diz geopoeticamente a compositora paraibana Catia de França, citando as flores que tornei a colher (bem depois de conhecer a canção) na obra literária que a inspirou: Grande Sertão: Veredas (Rosa, 2019). A imagem da bela e ruidosa gralha-cancã, ou cancão (Cyanocorax cyanopogon), pousada sobre o facheiro (Pilosocereus pachycladus), sintetiza a beleza e a singularidade da paisagem do semiárido brasileiro.

\footnotetext{
${ }^{3}$ https://www.palcomp3.com.br/chicolivino/festa-da-vida/

${ }^{4}$ https://www.youtube.com/watch?v=Ghyy7zfILtI

${ }^{5}$ Refere-se ao "inverno" em boa parte do país como o período das chuvas, que normalmente é inverso aos meses correspondentes ao inverno oficial.

${ }^{6} \mathrm{https}: / /$ www.youtube.com/watch?v=Op4fDScR2F0
} 


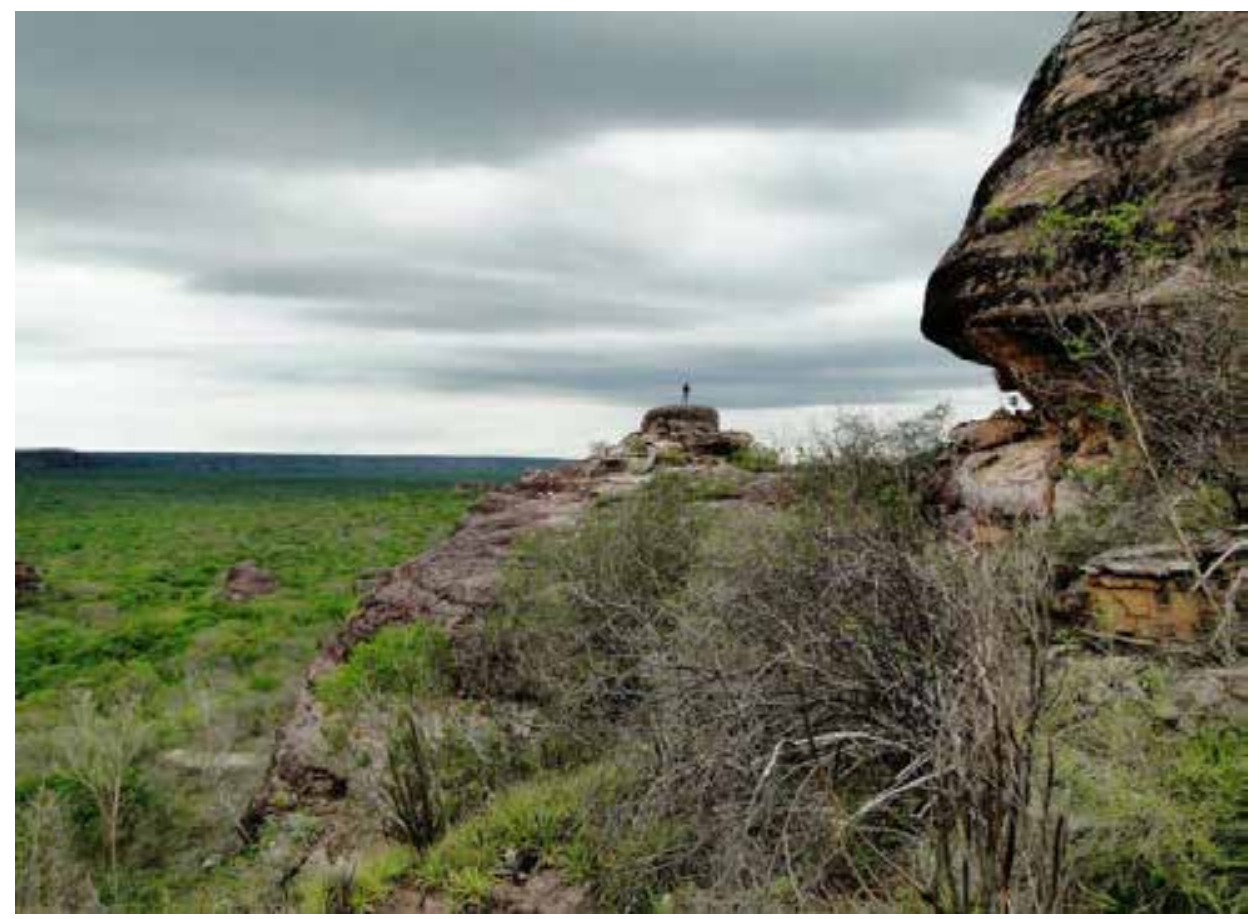

FIGURA 4 - O autor no Parque Nacional da Serra da Capivara-PI. FOTO: Rudolf Schwark.

A canção "Festa fresca, chuva boa!"”, última dentre as que ilustram este trabalho, se constrói sob a métrica decassílaba do martelo agalopado, estilo de poema utilizado por cordelistas e cantadores, o que, por si só, já introduz a ambiência regional, contribuindo para o retrato da "paisagem sonora" (Torres \& Kozel, 2012). Diferentemente da canção anterior, que festeja a vida, esta composição contraponteia a dialética de morte e vida, valendo-se desta para ressaltar a força e a resiliência dos habitantes da região, incluindo elementos vegetais, animais e culturais: "O sertanejo é, antes de tudo, um forte" (Cunha, 2016).
"Sentinela no alto dos garranchos/ Estala o açoite do galo de campina/"

Conhecido também como cardeal-do-nordeste (Paroaria dominicana), o galo-de-campina é das espécies mais características do semiárido nordestino, seja por sua abundância (apesar da grande pressão do comércio ilegal), seja por sua beleza, destacada principalmente pelo vermelho vivo que ostenta na cabeça (Ferreira, 2012). A imagem do pássaro cantando forte no alto das galhadas remete à vivacidade da fauna quando chega o período de chuvas, transmutando a paisagem catingueira.

\footnotetext{
${ }^{7}$ https://www.youtube.com/watch?v=nlqO9M0bqpA
} 
"Meu cavalo, renasce, encharca a crina/ Volta a vida alegrando o meu roçado/"

Destaca-se a ideia de renascimento. Impressão que povoa o cotidiano das populações expostas aos rigores das secas sazonais. A chegada das chuvas é o retorno da vida, interrompendo o ciclo de privações anuais que se abate sobre o território.

"Gota a gota... o piano em meu telhado/ Vai se a morte, a tristeza, a fome e a sede/"

A metáfora das gotas como teclas de piano vem do relato comovente de um fazendeiro que, depois de criado na Zona da Mata de Pernambuco, se transferiu para o município de Canto do Buriti-PI, em pleno semiárido. Seu relato da primeira chegada de chuva que presenciara, após as agruras de conviver com privações e mortes em seu rebanho, é comovente e, de certo modo, tornou-se um mote para essa composição. Contou-me acordar no meio da madrugada, ao ouvir os primeiros pingos grossos sobre a cobertura de telha vã de sua fazenda. Sem que fosse necessário chamar, um a um todos os membros de sua família foram acordando e indo para o terreiro dançar sob a chuva, agradecendo a dádiva recebida, que reabasteceria as forças para os desafios cotidianos do viver. Retrato comovente de uma região na qual os ciclos da Natureza ainda ditam os ciclos do homem, ao contrário das grandes metrópoles, nas quais as estações do ano e mesmo o dia e a noite já foram “domesticados", afastando o ser humano de seu berço (Tuan, 2013b).

"Vem cancão, vem concriz, na rama verde/ Chuva veio encobrindo a lua nova/ Hoje o chão é de pão ao invés de cova/ Festa fresca é a manhã, balança a rede/"

Aos já citados cancão e galo-de-campina, outra vistosa ave típica da caatinga se junta sobre a "rama verde" que reveste agora a vegetação. Trata-se do concriz, ou corrupião (Icterus jamacaii), com sua vistosa plumagem do amarelo pálido ao laranja forte, contrastando com o negro da cabeça, asas e cauda, que marca a paisagem visual e sonora do sertão, dono de forte e melodiosa voz. O contraste entre o "pão" e a "cova" sintetiza as duas faces de uma mesma terra, em um bioma singular. Vida e morte, aliás, não são mais do que vida. É na morte que a vida se transmuta em outra, no incessante fluxo energético da cadeia alimentar.

"Nem se lembra de ontem a terra palha/ Pasto bom, meu pé duro veste o osso/"

"A paisagem, espantosamente, se transmuta praticamente do dia para a noite!” (Barros, 2003). A Caatinga verde e viçosa nem de longe faz lembrar a paisagem cinza de poucos dias antes. O rústico gado "pé duro", que colonizou o interior do país a partir do Piauí, é trazido das chapadas, por onde campeou asselvajado durante o estio, para o manejo do fazendeiro nas pastagens renascidas.

"Sol de hoje é suave, é amigo nosso/ Sapo ou homem, faz festa, ri e trabalha/"

Parecendo surgir do nada, os sapos aparecem em profusão. Na verdade, têm o hábito de passar o período de seca enterrados em hibernação, de modo a proteger a umidade de seus corpos, fenômeno conhecido como "estivação" (Pereira, 2016). Tais “milagres" enriquecem o lado mítico da relação entre ser humano e Natureza, favorecendo a Geopoética. O conhecimento - no formato eurocentrado, ocidental e acadêmico - desconstrói mitos, e ao desconstruí-los se esvanece a poesia (Tuan, 2012). Apesar de serem entendidos atualmente por muitas pessoas apenas como sinônimo de mentiras, os mitos, assim como a Literatura, a Arte, a Filosofia e a Ciência, são na verdade formas diferentes de se fazer uma leitura da realidade e "pensar o mundo" (Ponciano, 2015). 
Essa aversão aos mitos dos povos tradicionais foi reforçada por muito tempo, estando correlacionada com a valorização da Ciência e da "racionalidade". O que talvez não tenha sido percebido pelos pesquisadores é que parte da nossa ancestralidade foi apagada junto com essa negação da importância dos mitos, além de desperdiçar o acesso a uma maneira muito mais "sustentável" de conservar a Natureza. Conforme os povos tradicionais nos alertam em seus mitos, estamos conectados a todos os elementos que nos cercam, bióticos e abióticos.

"Sulca o chão, põe semente, colhe a calha/ Água boa, sem barro de cacimba/"

As cacimbas barrentas, muitas vezes longe das casas, são, nos momentos de maior escassez, as únicas fontes possíveis de água para tantas famílias sertanejas. Beber uma água cristalina, colhida da calha da cobertura, pode ser um prazer tão intenso quanto simples. "Se a coisa não complica,/ Talvez eu seja uma bica/ Pela próxima invernada./ E inverno é chuva, é água,/ E eu encherei outras latas/ Cumprindo minha jornada" (Quirino, 1998).

"Tempo bom, na lavoura tudo vinga/ Garrafada pra festa e não doença/ $\mathrm{O}$ amor e o labor renovam a crença/ Hoje é vida e não morte na caatinga/"

É tempo de festa no sertão! As ervas medicinais agora se prestam somente à celebração, dando sabor à aguardente. Celebração da vida, do amor, do trabalho, da terra que, mesmo sujeita a privações, oferece sustento e autenticidade ao seu povo.

"Xique-xique e o facheiro cortam a carne/ Rasgam veios tal qual xilogravura/ Retratando as histórias de aventura/ Que aqui não se dão por pabulagem/"

A metáfora coloca frente a frente a rispidez da flora catingueira com a arte sertaneja. Os espinhos onipresentes na vegetação do semiárido (Prado,
2003) são aqui comparados às goivas que entalham a madeira para ilustrar os livretos de cordel com expressividade única (Carvalho, 1995). Versos e ilustrações se unem para retratar a paisagem, Geopoética empírica e onipresente.

"Pois vencer no Sertão é ter coragem/ E da luta é que vem a recompensa/Minhas armas eu trago de nascença/ São heranças de irmão, de pai, de avô/ Nessa vida eu me formei cantador/ Canto a chuva, a beleza, a vida intensa!"

As "armas", Arte e Ciência, estão postas para lutar pela vida. Sensibilidade e conhecimento a serviço das UC brasileiras, entrelaçando Geopoética, ecoturismo e conservação da Natureza.

\subsection{Geopoética em Arquitetura: Estação Ecológica do Raso da Catarina}

Morte e vida... Severina e animal... (Melo Neto, 2007). O ciclo constante de seca e renascimento é o drama anual encenado no anfiteatro guardado pelas ocres escarpas de arenito, nicho especial que se desenha ao sul da chapada sem fim do Raso da Catarina.

Assim como nas altas latitudes de longos invernos nevados, para as quais a nossa xenofilia distante costuma ser mais complacente ao drama, a vida aqui, quando permitido pelo clima, pulsa em extasiante intensidade. "É a festa da vida! É a vida com pressa... que bebe a chuva bem-vinda e anseia a chuva que resta".

Portentosos paredões de arenito, formados por cânions, escarpas e vertentes, marcam o contato entre os dois grandes domínios geomorfológicos dessa estação ecológica: o planalto Marizal e a formação São Sebastião, ao sul da unidade. Sítio de dormitório 
e nidificação das araras-azuis-de-lear (Anodorhyinchus leari) - espécie ameaçada e endêmica dessa região da caatinga, importante "espécie-bandeira" da ESEC - esta região apresenta beleza cênica impressionante, por suas características naturais. Guarda ainda em suas entranhas as histórias da odisseia de Canudos e do cangaço brasileiro, tendo servido de refúgio por diversas vezes para os guerreiros de Lampião, dentre outros combatentes sertanejos. Desse modo, a ESEC Raso da Catarina representa um importante patrimônio cultural brasileiro (Cunha, 2016; Paes \& Dias, 2008).
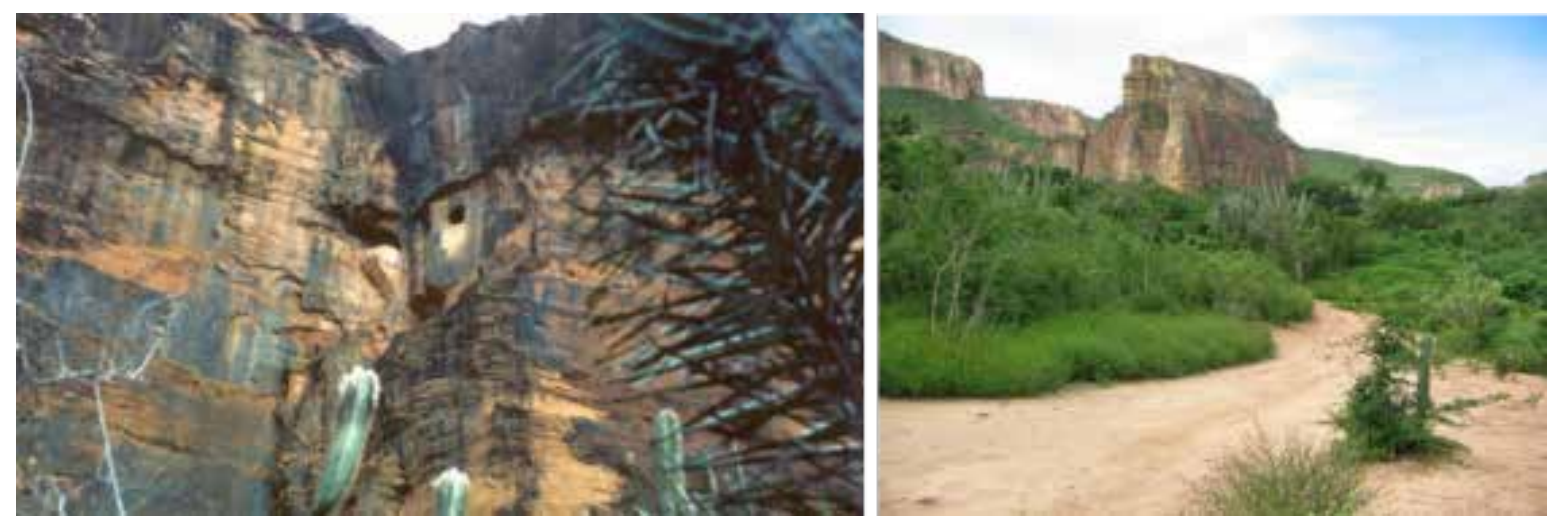

FIGURA 5 - Paredões de arenito, com detalhe à esquerda de ninho de arara. FOTOS: Primeiro autor.

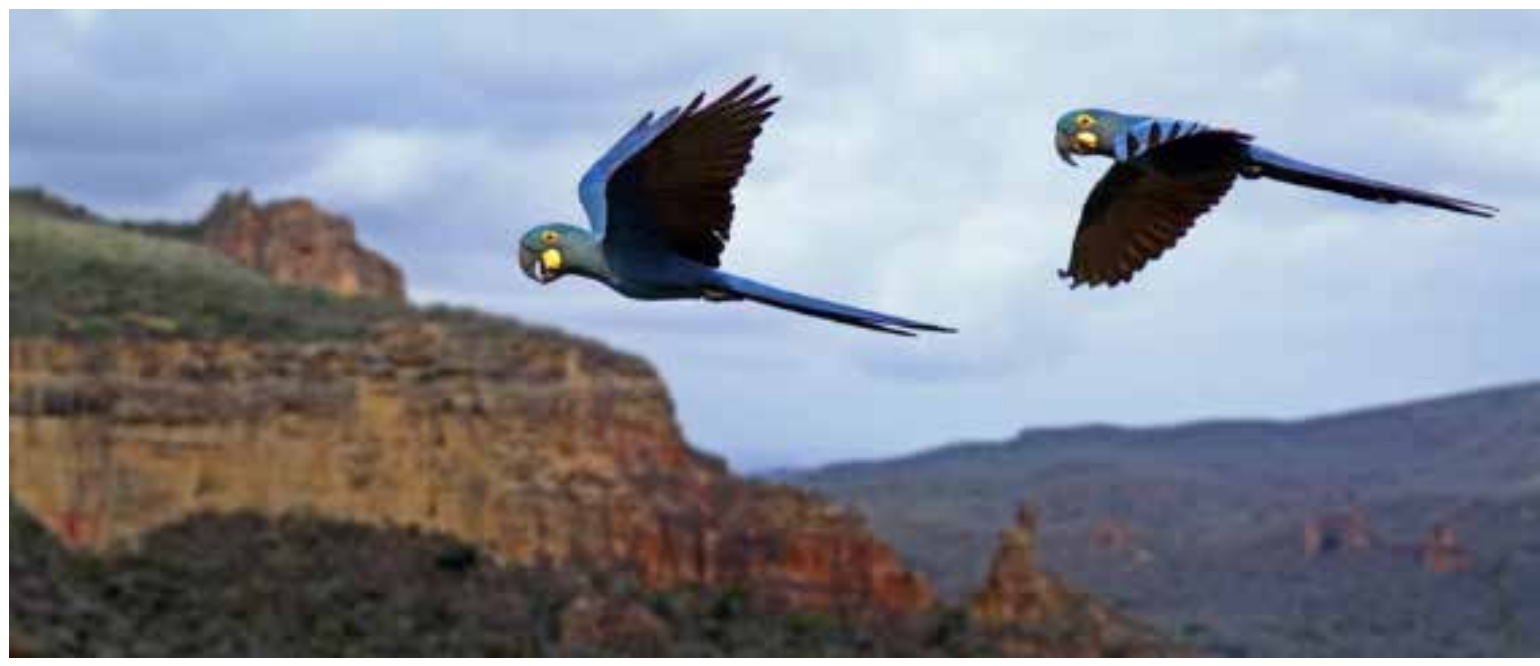

FIGURA 6 - Anodorhynchus leari no Raso da Catarina.

FONTE: https://pt.wikipedia.org/wiki/Arara-azul-de-lear. 
A base de pesquisa foi projetada ao sul desse anfiteatro de arenito, inicialmente no ano de 2007. Este projeto foi revisitado atualmente, junto a outros projetos, sob as lentes da Geopoética. Este edifício, em vez de ser implantado, isto é, como algo de fora imposto ao lugar, se pretende como uma "eclosão" das forças expressivas da paisagem natural de seu sítio (Crapez, 2015).

Cada detalhe expressivo da edificação foi pensado como uma tradução das cores e formas da exuberante Caatinga local, buscando-se técnicas construtivas adequadas para a materialização das ideias concebidas sob tal inspiração. Referências nas práticas de "construção natural" (Soares, 2007) foram as principais fontes utilizadas, no sentido de minimizar os impactos ambientais da construção e do uso da edificação, buscando adaptar o projeto aos materiais e técnicas disponíveis localmente e, portanto, a um menor custo, tanto econômico quanto ambiental.

Forma e função flertam entre si a todo o momento, sempre objetivando materializações plásticas resultantes das técnicas utilizadas e que se refletirão na vivência do edifício, priorizando as técnicas passivas de conforto térmico.

As paredes executadas em tijolos de solo-cimento, por exemplo, trazem a tonalidade do solo local para as fachadas, mimetizando-as no contexto paisagístico local. Nelas foram projetados pequenos vãos irregulares que provocam uma ventilação cruzada, aproveitando o microclima ameno que o frondoso umbuzeiro (Spondias tuberosa) oferece no pátio central da edificação (Figura 7). "É a árvore sagrada do sertão. Sócia fiel das rápidas horas feli-

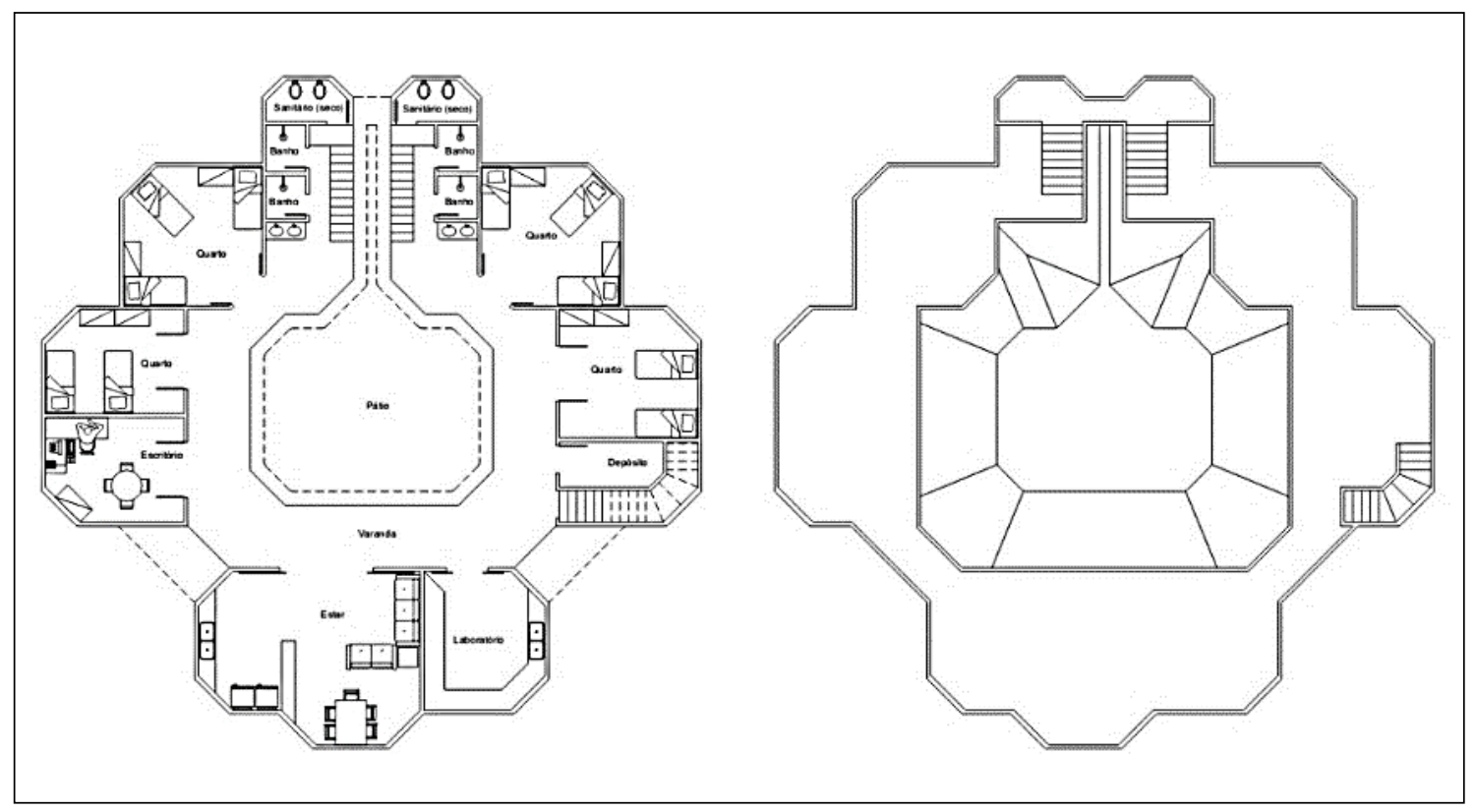

FIGURA 7 - Edificação voltada "para dentro" em torno do umbuzeiro. FONTE: desenho do primeiro autor. 
zes e longos dias amargos dos vaqueiros" (Cunha, 2016). Sob os rigores do semiárido nordestino, a Arquitetura se associa à flora e se fortalecem como abrigo. Emolduradas pelos terraços-jardim que abrigam plantas típicas da localidade, as citadas paredes respondem integralmente pela volumetria da edificação, que se oferece como discreta e pequena louvação aos portentosos paredões que desenham o horizonte. Face ao reduzido porte geral da flora do semiárido, o terraço da edificação torna-se um privilegiado posto de observação, um convite para a contemplação das noites ímpares na Caatinga, sob o célebre "luar do sertão".

Os pequenos vãos citados, construídos com o fim de promover conforto térmico à edificação, resultam em releituras dos ninhos das araras que ponteiam os paredões em redor. A técnica do solo-cimento (blocos prensados com uma pequena dosagem de cimento no traço) não requer a queima, o que ajuda a proteger a madeira nativa, tantas vezes utilizada irregularmente em olarias pelo país.

Outra técnica de baixo impacto ambiental é a utilização de banheiros secos (compostáveis), que se valem da intensa insolação local para produzir compostos dos dejetos, que podem inclusive servir de adubo depois de completado o processo. Sendo a região do Raso da Catarina uma das mais secas do país, reduz-se significativamente a demanda por água na edificação, uma vez que esta não é usada em descargas de vasos sanitários.

Aspectos referentes ao programa de necessidades da edificação e outras questões técnicas não são aqui abordados, uma vez que o cerne da discussão é a interface edificação/paisagem, nosso foco (Figura 8).

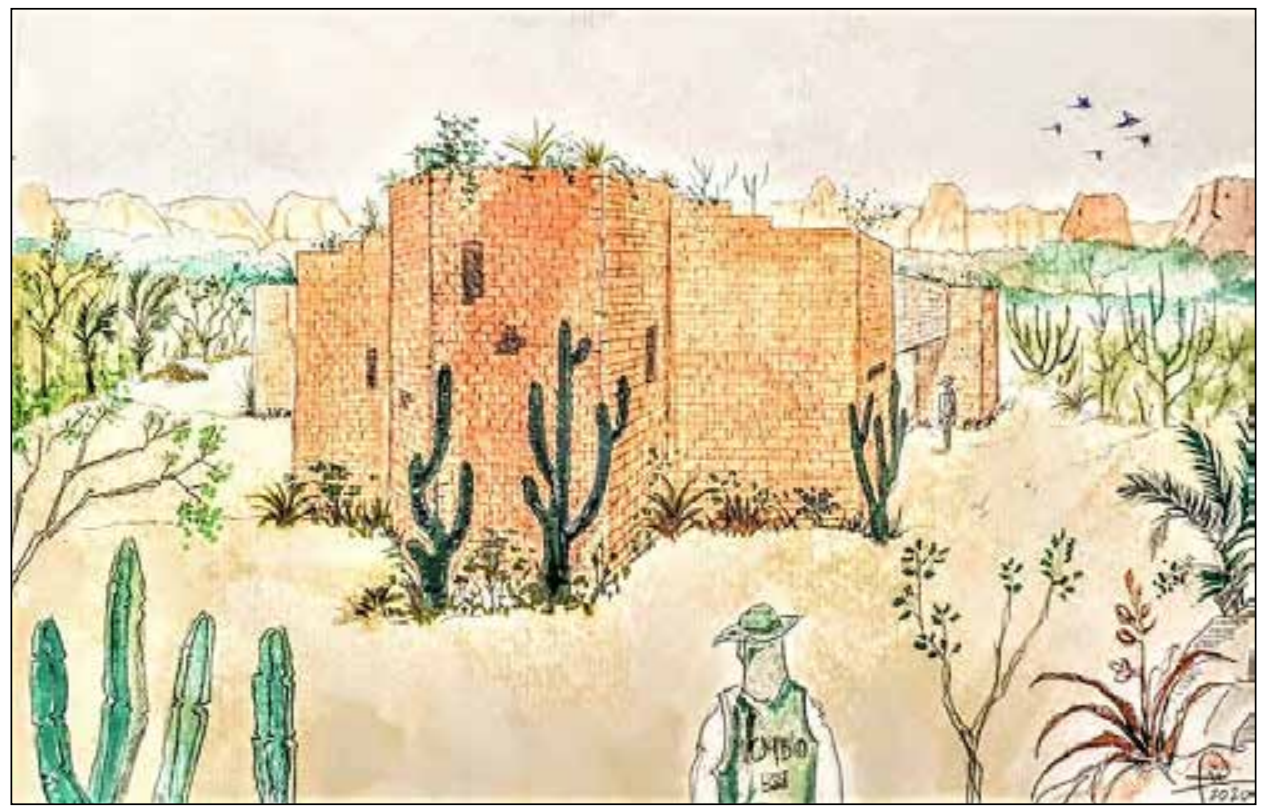

FIGURA 8 - Perspectiva ilustrando a inserção da edificação na paisagem. FONTE: ilustração do primeiro autor. 
Atendo-se ao aspecto geral do prédio proposto, não se reconhecem as linhas comuns das águas de telhados, paredes lisas pintadas, esquadrias industriais e outras tantas convenções comumente presentes nas edificações que estruturam nossos bairros residenciais e, surpreendentemente, também as nossas UC.

A edificação que propomos, ao contrário, aproximar-se-ia muito mais das taperas de taipa ou adobe que resultam da prática vernacular do homem sertanejo. Em virtude de sua volumetria ortogonal, entretanto, se diferencia das linhas clássicas dos abrigos humanos, nitidamente marcados pelas paredes verticais guarnecidas pelos planos inclinados dos telhados ou palhoças. Pode-se dizer, olhando a perspectiva aqui exposta, que a base de pesquisa da ESEC Raso da Catarina estaria mais para uma "germinação", um "broto" de uma das escarpas rochosas que a rodeiam, do que para uma intervenção humana na paisagem, tal qual o desejo ilustrado pelo poema que dá nome à dissertação da qual se extrai o presente trabalho: "Quero então, como miragem, Mimetismo que se mostra e quase engana/ Que se quer fazer parte da paisagem/ Varanda não, Varandarana".

A estrutura da edificação se inicia na concepção daquilo que se quer expressar e nas escolhas (tecnológicas, sociais, plásticas, etc.) que se fazem necessárias. Assim nasce a Arquitetura.

\section{Referências}

Amazan. Dez poemas engraçados. Somzoom, 1994. CD

Andrade, D. F. de; Sorrentino, M. Da gestão ambiental à educação ambiental: as dimensões subjetiva e intersubjetiva

\section{Considerações finais}

A vida que pulsa nas áreas naturais protegidas é, ao mesmo tempo, o motivo e a recompensa daqueles que trabalham por elas. Tal motivo é traduzido neste artigo, no objetivo de promover o encantamento por meio da Arte, seja ela construída com terra e cimento, seja ela construída com palavras e sons. Em ambos os casos buscamos o encontro, a escuta e a propagação da linguagem da Terra, por meio da Geopoética.

Entrelaçamos Arquitetura e canção, retroalimentando-se, mirando a sensibilidade do interlocutor por sentidos variados e integrando os sentimentos com a razão.

No trabalho que aqui se conclui, técnica e poética se complementam, com o intuito de despertar o (re)encantamento das pessoas pela Natureza (enfocando as UC brasileiras) por meio da interpretação ambiental, divulgando e promovendo a importância da conservação da biodiversidade, da geodiversidade e da cultura local de forma integrada e transdisciplinar.

É pela força desta relação dialética e dialógica que se quer construir - com paredes, vãos, pisos e coberturas unidas com versos, prosas, melodias, ritmos e imagens - uma Geopoética dos biomas brasileiros, enfocando aqui o semiárido, a Caatinga, nosso único bioma 100\% nacional.

nas práticas de educação ambiental. Pesquisa em Educação Ambiental, 8, 88-98, 2013. doi: 10.18675/2177-580X 
Barros, M. L. B. Prefácio. In: Leal, I. R.; Tabarelli, M.; Silva, J. M. C. da. Ecologia e conservação da Caatinga. Recife: Universitária da UFPE, 2003. p. 9-11, 2003.

Cabrita, F. S. G. V. N. Arquitetura e persuasão nos meios de hospedagem ecoturísticos: uma análise retórica de um caso na ilha de Santa Catarina. Florianópolis. Dissertação (Mestrado em Arquitetura e Urbanismo) - UFSC, 2017. Disponível em: https://repositorio.ufsc.br/handle/123456789/185639

Carvalho, G. de. Xilogravura: os percursos da criação popular. Revista do Instituto de Estudos Brasileiros, 39, 143158, 1995. doi: 10.11606/issn.2316-901X.v0i39p143-158

Castiglioni, G. D. A. Biologia reprodutiva e organização social de Ramphocelus bresilius (Passeriformes: Emberizidae) na restinga de Barra de Marica, Estado do Rio de Janeiro. Campinas.. Dissertação (Mestrado em Ciências Biológicas) - UNICAMP, 1998. Disponível em: http:// repositorio.unicamp.br/jspui/handle/REPOSIP/316221

Cordel do Fogo Encantado. O palhaço do circo sem futuro. Independente, 2002. CD.

Crapez, P. Imagens da cidade e Geopoética. Niterói, Tese (Doutorado em Arquitetura e Urbanismo) - Universidade Federal Fluminense, 2015.

Crapez, P. Por uma geopoética urbana: Arte, Cidade, Paisagem. Geograficidade, 7, 49-60, 2017. Disponível em: https://periodicos.uff.br/geograficidade/article/view/12980/ pdf

Cruz, E. P. Plantas, animais, biólogos e outros entes na caatinga: notas etnográficas em mundos de areia. Salvador, Tese (Doutorado em Ciências Sociais) - Universidade Federal da Bahia, 2018.

Cunha, E. da. Os Sertões. São Paulo: Martin Claret, 2016.

Ferreira, J. Contribuição da genética de populações à investigação sobre o tráfico de fauna no Brasil: desenvolvimento de microssatélites e análise da estrutura genética em Paroaria dominicana e Saltator similis (Aves: Passeriformes: Thraupidade). São Paulo, Tese (Doutorado em Biologia-Genética) - USP, 2012. doi: 10.11606/T.41.2012. tde-17122012-200300

Ferreira, L. Árido Movie. Filme. 2005.
França, C. de. Vinte palavras ao redor do sol. Epic, CBS. 1979. LP.

Frey, K. Políticas públicas: um debate conceitual e reflexões referentes à prática da análise de políticas públicas no brasil. Planejamento e Políticas Públicas, 52, 211-259, 2000. Disponível em: http://www.ipea.gov.br/ppp/index. php/PPP/article/view/89

Guimarães, S. T. de L. Reflexões a respeito da paisagem vivida, topofilia e topofobia à luz dos estudos sobre experiência, percepção e interpretação ambiental. Geosul, 33, 117-141, 2002. Disponível em: <https://periodicos.ufsc.br/ index.php/geosul/article/view/13971/12802>

Hanai, F. Y.; Netto, J. P. da S. Instalações ecoturísticas em espaços naturais de visitação: meios para propiciar a percepção e a interpretação ambientais. OLAM Ciência \& Tecnologia, 6, 200-223, 2006.

ICMBio - Instituto Chico Mendes de Conservação da Biodiversidade. Interpretação Ambiental nas UC Federais, 2018. Disponível em: <http://www.icmbio.gov.br/portal/ images/stories/comunicacao/publicacoes/publicacoes-diversas/interpretacao_ambiental_nas_unidades_de_conservacao_federais.pdf $>$. Acesso em: fev. 2019.

Kozel, S. Geopoética das paisagens: olhar, sentir e ouvir a "Natureza". Caderno de Geografia, 37, 65-78, 2012. Disponível em: $<$ http://periodicos.pucminas.br/index.php/ geografia/article/view/3418>

Leme, F. B. M.; Neves, S. C. Dos ecos do turismo aos ecos da paisagem: análises das tendências do ecoturismo e a percepção de suas paisagens. Pasos - Revista de Turismo e Patrimônio Cultural, 5, 209-223, 2007. doi: 10.25145/j. pasos.2007.05.016

Mello, E. F. Das barrancas do Rio Gavião. Polygram, 1973. LP.

Mello, E. F. Fantasia leiga para um rio seco. Rio do Gavião, 1981. LP.

Melo Neto, J. C. de. Morte e vida severina e outros poemas. Rio de. Janeiro: Alfaguara, 2007.

Mendonça, R.; Neiman, Z. Ecoturismo: discurso, desejo e realidade. Turismo em Análise, 11, 98-110, 2000. doi: 10.11606/issn.1984-4867.v11i2p98-110 
Mestre Ambrósio. Fuá na Casa de Cabral. Chaos, 1998. CD.

Mestre Ambrósio. Terceiro Samba. Sony, 2001. CD.

Oliveira, H. C. de. Um sertão Elomariano: identidade e modernidade na obra de Elomar Figueira Mello. Estudos de Literatura Brasileira Contemporânea, 54, 361-392, 2018. doi: 10.1590/10.1590/2316-40185419

Paes, M. L. N.; Dias, I. de F. O. Plano de manejo: Estação Ecológica Raso da Catarina, 2008. Disponível em: $<$ http:// www.icmbio.gov.br/portal/images/stories/imgs-unidades-coservacao/esec_raso_da_catarina.pdf $>$. Acesso em: 22 jul. 2019.

Pedrosa, C. Sertão Caboclo. Independente, 2001. CD.

Pereira, I. C. Estratégias fisiológicas e comportamentais em anuros no semiárido: implicações sobre o balanço energético e hídrico. São Paulo, Tese (Doutorado em Fisiologia) - USP, 2016.

Ponciano, L. C. M. O. Geomitologia: Era uma vez... na história da Terra. Revista Sentidos da Cultura. 2, 22-42, 2015. Disponível em: https://paginas.uepa.br/seer/index. php/sentidos/article/view/596

Ponciano, L. C. M. de O. Geotales: narrando as histórias petrificadas pela Terra. Revista Sentidos da Cultura, 5, 3448, 2018. Disponível em: https://paginas.uepa.br/seer/index. $\mathrm{php} /$ sentidos/article/view/2010

Prado, D. E. As Caatingas da América do Sul. In: Leal, I. R.; Tabarelli, M.; Silva, J. M. C. (Eds.). Ecologia e conservação da Caatinga. Recife: Editora UFPE, 2003. p. 3-74.

Queiroz, R. de. O quinze. Rio de Janeiro: José Olympio, 2006.

Quirino, J. Agruras da Lata d'Água. Recife: Bagaço, 1998.

Quirino, J. Prosa morena. Recife: Bagaço, 2005.

Ricardo, S. A Noite do Espantalho. 1974. Cinema.

Roncaglio, C. A ideia da Natureza como patrimônio: um percurso histórico. Desenvolvimento e Meio Ambiente, 19, 111-128, 2009. doi: 10.5380/dma.v19i0.14517
Rocha, G. O Dragão da Maldade contra o Santo Guerreiro. 1969. Cinema.

Rosa, G. Grande Sertão: Veredas. São Paulo: Companhia das Letras, 2019.

Salles, W. Central do Brasil. 1998. Cinema.

Samico, G. Samico. Rio de Janeiro: Centro Cultural Banco do Brasil, 1998.

Sampaio, C. A. C.; Parks, C. D.; Mantovaneli Jr., O.; Quinlan, R. J.; Alcântara, L. C. S. Bem Viver e Ecossocioeconomias: uma síntese. Desenvolvimento e Meio Ambiente, 47, 121-128, 2018. doi: 10.5380/dma.v47i0.62431

Soares, A. Soluções sustentáveis: construção natural. Pirenópolis: Calango, 2007.

Tilden, F. Interpreting our Heritage. North Caroline: Chapel Hill, 1977.

Torres, M. A.; Kozel, S. A paisagem sonora da Ilha dos Valadares: percepção e memória na construção do espaço. In: Barthe-Deloizy, F.; Serpa, A. (Orgs.). Visões do Brasil: estudos culturais em Geografia [on-line]. Salvador: EDUFBA; Edições L'Harmattan, 2012. p. 167-190. Disponível em: <http://books.scielo.org/id/8pk8p/pdf/ barthe-9788523212384-10.pdf $>$

Tuan, Y. F. Topofilia: um estudo da percepção, atitudes e valores do meio ambiente. Londrina: Eduel, 2012.

Tuan, Y. F. A cidade: sua distância da Natureza. Geograficidade, 3(1), 4-16, 2013a. doi: 10.22409/geograficidade2013.31.a12826

Tuan, Y. F. Espaço e lugar: a perspectiva da experiência. Londrina: Eduel, 2013b.

White, K. No ateliê geopoético. 1999. Disponível em: $<$ https://www.institut-geopoetique.org/pt/textos-fundadores/105-no-atelie-geopoetico>

White, K. Precisões. 2014. Disponível em: < https://www. institut-geopoetique.org/pt/textos-fundadores/62-precisoes>

Xangai. Cantoria de Festa. Kuarup, 1997. CD. 